\title{
The Role of Modern Methods of Examination in Assessing the Effect of Smoking on the Course of Bronchial Asthma and Development of Comorbid Metabolic Pathology
}

DOI: 10.17691/stm2017.9.2.12

Received June 6, 2016

V.A. Vakhlamov, MD, PhD, Tutor, Department of Propedeutics of Internal Diseases

Nizhny Novgorod State Medical Academy, 10/1 Minin and Pozharsky Square, Nizhny Novgorod, 603005, Russian Federation

The aim of the investigation was to demonstrate the feasibilities of using up-to-date methods of examination for assessing the effect of smoking on the course of bronchial asthma (BA) and development of comorbid metabolic pathology.

Materials and Methods. 201 patients with noncontrolled BA were investigated. Group 1 comprised 152 nonsmoking patients, group 2 included 18 smokers, group 3 consisted of 31 heavy smokers. Along with the general clinical methods of examination, external respiration function with evaluation of forced life capacity, forced expiratory volume in 1 second, and Tiffeneau index were investigated. To diagnose obesity, a bioelectrical impedance analysis was used, body mass index was determined, and waist measurements were performed. To study the carbohydrate metabolism, the level of glycated hemoglobin ( $\mathrm{HbA1c}$ ), immunoreactive insulin, and C-peptide were estimated.

Results. Waist measurements, bioelectrical impedance analysis, determination $\mathrm{HbA} 1 \mathrm{c}$, immunoreactive insulin, and C-peptide levels are established to play a great role in the diagnosis of comorbid endocrine pathology in BA. The severity of the disease in BA patients is aggravated by visceral obesity and diabetes mellitus, and cigarette smoking is an essential risk factor of their development. Longterm heavy smokers with BA are characterized by the addition of chronic obstructive pulmonary disease and the development of overlap syndrome with an extremely severe course.

Key words: bronchial asthma; obesity; diabetes mellitus; cigarette smoking; overlap syndrome.

At present, bronchial asthma (BA) is a top priority disease among the illnesses of the pulmunological profile. Its prevalence on the Russian Federation territory is in the range from 1 to $12 \%[1,2]$. In the last years there appeared many works about BA frequently running in combination with hypertension disease, ischemic heart disease, diabetes mellitus (DM), obesity, and metabolic syndrome [1-13]. BA was established to develop more often in obese patients than in general population [1-4]. Various studies confirm a dosedependent association between these pathologies [1]. In comorbidity of BA with a metabolic syndrome, its clinical course is usually more severe, with frequent exacerbations and admissions, a significantly lower spirometric indices, and even failure to control the patient's state in hospital conditions [1-13].

Cigarette smoking is recognized to be a leading and universal risk factor of bronchopulmonary, cardiovascular, and metabolic pathology. This harmful habit is associated with a progressive reduction of pulmonary function, decreasing response to glucocorticoid therapy [2, 11]. Increase of basic drug doses, excessive intake of short-acting $\beta_{2}$-agonists, progressive arterial hypoxemia in combination with other multiple factors triggers the vicious circle of the pathogenesis of cardiovascular and metabolic diseases, which, in turn, aggravate the course of BA. AsthmaCOPD (chronic obstructive pulmonary disease) overlap syndrome, actively being discussed in the current literature [14-16], is presently of special importance. It should be taken into consideration that the quality of life in many smokers with BA is sharply worsening due to often exacerbations, the pulmonary function is rapidly diminishing, and patients die. But the fine details of smoking effect on the bronchopulmonary and metabolic pathology is sometimes not easy to trace. In this work, we attempted to assess the effect of cigarette smoking in people with BA, including overlap syndrome, on the development of comorbid disorders and diseases using additional advanced methods.

The aim of the investigation was to demonstrate the feasibilities of up-to-date examination methods in the assessment of the effect of smoking on the course of bronchial asthma and development of comorbid metabolic pathology.

Materials and Methods. 201 patients with uncontrolled BA, treated in a specialized pulmonological department of City Clinical Hospital No.10 in Nizhny Novgorod. The diagnosis was verified according to GINA criteria [2, 14]. All patients were divided into 3 groups: group 1 consisted of 152 nonsmoking patients, group 2 included 18 smokers (including former smokers),

For contacts: Vladimir A. Vakhlamov, e-mail: mlpu10@mail.ru 
group 3 was comprised of 31 heavy smokers. It was in the patients of the latter group that asthma-COPD overlap syndrome was presented, whereas the first two groups were examined for comparison.

The study complies with the Declaration of Helsinki (the Declaration was passed in June 1964, Helsinki, Finland and revised in October 2000, Edinburgh, Scotland) and was performed following approval by the Ethic Committee of Nizhny Novgorod State Medical Academy. Written informed consent was obtained from every patient.

Along with the general clinical methods of examination, external respiration function with evaluation of forced life capacity, forced expiratory volume in 1 second, and Tiffeneau index using SPIROVIT SP-1 spirometer (Shiller AG, Switzerland), were investigated. Currently, verification of visceral obesity is based on computed or magnetic resonance tomography [17]. However, these methods are rather expensive, therefore to determine a percentage of adipose tissue as well as visceral fat in the body, a bioelectrical impedance analysis was performed using Body Composition Monitor BF 508 (OMRON, Japan). We could not find any data of using this system for similar investigations in the available literature. Besides, body mass index (BMI) was calculated and waist measurements for all patients were performed.

To study carbohydrate metabolism, in addition to the indices of blood glycemia, the level of glycated hemoglobin (HbA1c) was determined by means of automated D-10 analyzer (Bio-Rad, USA), tested and certified according to NGSP (National Glycohemoglobin Standardization Program), which is thought by some authors to be the most accurate device used on the Russian Federation territory [18]. Immunoreactive insulin (IRI) and C-peptide were determined using electrochemiluminescence Roche Elecsys 2010 immunology analyzer (Roche, Switzerland).
Data were statistically processed using Minitab 16 and Statistica 7.0 programs. At the beginning of the data analysis, the normality of variable distribution was determined by Anderson-Darling test. Extended variables were presented as arithmetic mean (M) and standard deviation (SD) or as median (Me) and quartiles (Q1; Q3). Two independent groups were compared using Student's t-test and Mann-Whitney test. Criterion $X^{2}$ was used to compare frequencies. In order to measure linear relationships between phenomena, Pearson's correlation coefficient (r), Spearman's rank correlation (Rs), and Gamma criterion were applied. If $p$-value was insignificant, the abbreviation "Ins" was used in the tables.

Results and Discussion. In the majority of the examined patients, significant mixed impairments of external respiration function were observed (Table 1). And intensive smoking promoted significant diminishing of all ventilation constants. Nonsmokers with BA appeared to be the most compliant patients (they received supporting inhalation therapy with glucocorticoids). In group 2 the correct treatment was established only in $44 \%$ of cases. Long-term and intensive smoking resulted in the development of severe mixed impairments of pulmonary ventilation impelling these patients to listen to doctor's recommendations and to receive supporting therapy, and the number of compliant patients in group 3 reached $68 \%$, though it still turned out to be significantly lower than in the group of nonsmoking patients with $B A\left(X_{1-3}^{2}=6.5 ; p=0.011\right)$.

At the next stage, metabolic disorders in smoking and nonsmoking patients with BA were studied in detail. The prevalence of DM in all patients was higher than in the population (Table 2). And in the smokers it reached $34.5 \%$ (group $2+$ group 3 ). The analyses for postprandial glycemia and $\mathrm{HbA} 1 \mathrm{c}$ enabled us to establish for the first time the diagnosis of DM in $4.5 \%$ of patients from group 1.

Table 1

Description of the examined smoking and nonsmoking patients with bronchial asthma (M $\pm S D)$

\begin{tabular}{lcccc}
\hline \multicolumn{1}{c}{ Parameters } & $\begin{array}{c}\text { Group 1 } \\
\text { (nonsmokers) }\end{array}$ & $\begin{array}{c}\text { Group 2 } \\
\text { (smokers) }\end{array}$ & $\begin{array}{c}\text { Group 3 } \\
\text { (heavy smokers) }\end{array}$ & X; $p$ \\
\hline Age (years) & $62.2 \pm 9.4$ & $58.5 \pm 7.2$ & $60.6 \pm 10.2$ & Ins \\
\hline $\begin{array}{l}\text { Duration of asthma (years), } \\
\text { Me [Q1; Q3] }\end{array}$ & $10[3 ; 18]$ & $5[1.37 ; 10.25]$ & $8[4 ; 14]$ & Ins \\
\hline $\begin{array}{l}\text { A number of compliant } \\
\text { patients (\%) }\end{array}$ & 80.92 & 44.44 & 67.74 & $\begin{array}{c}X_{1-3}^{2}=6.5 ; p=0.011 \\
X_{1-2}^{2}=19.15 ; p=0.000 \\
X_{2-3}^{2}=2.56 ; p=0.109\end{array}$ \\
\hline $\begin{array}{l}\text { Forced life capacity (\%) } \\
\text { Forced expiratory volume } \\
\text { in 1 second (\%) }\end{array}$ & $70.76 \pm 22.36$ & $65 \pm 20.62$ & $54.19 \pm 18.39$ & $p_{1-3}=0.001$ \\
\hline Tiffeneau index & $70.01 \pm 26.77$ & $63.28 \pm 25.36$ & $43.23 \pm 17.61$ & $p_{1-3}=0.000 ; p_{2-3}=0.007$ \\
\hline
\end{tabular}


Table 2

Occurrence of diabetes mellitus and obesity in smoking and nonsmoking patients with bronchial asthma (\%)

\begin{tabular}{|c|c|c|c|c|c|}
\hline Parameters & $\begin{array}{c}\text { Group 1 } \\
\text { (nonsmokers) }\end{array}$ & $\begin{array}{c}\text { Group } 2 \\
\text { (smokers) }\end{array}$ & $\begin{array}{c}\text { Group } 3 \\
\text { (heavy smokers) }\end{array}$ & $\begin{array}{c}\text { All } \\
\text { smokers }\end{array}$ & $x^{2} ; p$ \\
\hline $\begin{array}{l}\text { Occurrence of diabetes } \\
\text { mellitus }\end{array}$ & 18.4 & 38.9 & 32.2 & 34.5 & $\begin{array}{c}X^{2}{ }_{1-2}=4.12 ; p=0.042 \\
X^{2}{ }_{1-3}=3.0 ; p=0.083 \\
X_{1-2+3}^{2}=5.65 ; p=0.017\end{array}$ \\
\hline Occurrence of obesity & 37.5 & 66.7 & 61.3 & 63.3 & $\begin{array}{c}X^{2}{ }_{1-2}=5.68 ; p=0.017 \\
X^{2}{ }_{1-3}=6.0 ; p=0.014 \\
X^{2}{ }_{1-2+3}=9.99 ; p=0.002\end{array}$ \\
\hline Occurrence of hypertension & 94 & 93 & 90 & - & Ins \\
\hline
\end{tabular}

Table 3

Metabolic indices in smoking and nonsmoking patients with bronchial asthma (MISD)

\begin{tabular}{lcccc}
\hline \multicolumn{1}{c}{ Parameters } & $\begin{array}{c}\text { Group 1 } \\
\text { (nonsmokers) }\end{array}$ & $\begin{array}{c}\text { Group 2 } \\
\text { (smokers) }\end{array}$ & $\begin{array}{c}\text { Group 3 } \\
\text { (heavy smokers) }\end{array}$ & $p$ \\
\hline Body mass index $\left(\mathrm{kg} / \mathrm{m}^{2}\right)$ & $33.02 \pm 6.78$ & $33.22 \pm 7.0$ & $32.02 \pm 6.45$ & Ins \\
\hline Waist measurements $(\mathrm{cm})$ & $107.80 \pm 13.69$ & $108.88 \pm 13.85$ & $113.71 \pm 16.45$ & $p_{1-3}=0.038$ \\
\hline $\begin{array}{l}\text { Percentage of adipose tissue } \\
\text { Percentage of visceral fat }\end{array}$ & $44.17 \pm 8.81$ & $40.70 \pm 13.05$ & $28.41 \pm 9.34$ & $p_{1-3}=0.000 ; p_{2-3}=0.004$ \\
\hline HbA1c $(\%)$, diabetes mellitus patients & $12.39 \pm 3.06$ & $13.29 \pm 2.59$ & $13.76 \pm 5.06$ & Ins \\
\hline $\begin{array}{l}\text { Immunoreactive insulin }(\mu \mathrm{lU} / \mathrm{ml}), \\
\text { diabetes mellitus patients }\end{array}$ & $13.09 \pm 1.35$ & $7.97 \pm 2.41$ & $8.31 \pm 1.94$ & Ins \\
\hline $\begin{array}{l}\text { C-peptide }(\mathrm{ng} / \mathrm{ml}) \text {, diabetes mellitus } \\
\text { patients }\end{array}$ & $5.55 \pm 2.32$ & $4.39 \pm 1.28$ & $5.82 \pm 1.53$ & $p_{1-3}=0.076$ \\
\hline
\end{tabular}

Asthma-COPD overlap syndrome (group 3) was also accompanied statistically significantly more often by comorbid obesity (determined by BMI), which reached $61.3 \%$ occurrence in group 3 . Some statistically insignificant reduction of obesity rate in group 3 relative to group 2 was thought by us to be due to addition of COPD, which has considerable systemic manifestations. Absolute majority of the examined patients had concomitant hypertension disease. Differences between the groups appeared to be statistically insignificant.

The analysis of the nutritional status showed that mean BMI values in all groups corresponded to the first degree of obesity (Table 3). Waist measurements demonstrated an interesting tendency, reaching in group 3 (overlap syndrome) the value of $113.71 \pm 16.45 \mathrm{~cm}$ and being statistically significantly higher than in group $1\left(p_{1-3}=0.038\right)$. At the same time, statistically significant decrease of adipose tissue percentage was noted in intensively smoking patients. Thus, obesity was typical for the majority of BA patients. Long-term heavy smokers were characterized by the reduction of the total fat mass, which, however, was redistributed to the abdominal viscera area, confirming the presence of metabolic syndrome. Application of bioelectrical impedance analysis made it possible to describe more precisely the changes of the nutritional status in overlap syndrome.

The study of carbohydrate metabolism showed that indices of glycemia (fasting and postprandial) between the groups did not differ significantly, and we decided not to present them here. Values of $\mathrm{HbA} 1 \mathrm{c}$ and IRI in patients with DM slightly grew from group 1 to 3 , but the difference between the groups reached only the level of statistical tendency and only in case of IRI $\left(p_{1-3}=0.076\right)$. It should be noted that the majority of the examined patients had a marked hyperinsulinemia.

In order to analyze the metabolic profile in BA in more detail, other statistical methods were applied. Thus, a correlation analysis revealed statistically significant positive correlation between a pack-year index and the visceral fat volume $(r=0.334 ; p=0.041)$, which once again confirmed the effect of smoking on the development of metabolic syndrome (Table 4). There was established a distinct statistical tendency to the presence of negative correlation between a pack-year index and percentage of adipose tissue in the body $\left(R_{S}=-0.277 ; p=0.072\right)$. The age at starting smoking and its duration did not correlate with the nutritional status parameters. Somewhat other 
Table 4

Correlations between nutritional status parameters and cigarette smoking in patients with bronchial asthma

\begin{tabular}{llc}
\hline \multicolumn{1}{c}{ Parameters } & \multicolumn{1}{c}{$\begin{array}{c}\text { Percentage } \\
\text { of adipose tissue }\end{array}$} & $\begin{array}{c}\text { Percentage } \\
\text { of visceral fat }\end{array}$ \\
$\begin{array}{l}\text { Duration of smoking } \\
\text { (years) }\end{array}$ & $r=-0.180 ; p=0.247$ & $r=-0.052 ; p=0.742$ \\
\hline $\begin{array}{l}\text { Pack-year index } \\
\text { Age at starting smoking } \\
\text { (years) }\end{array}$ & $R_{S}=-0.277 ; p=0.072$ & $r=0.334 ; p=0.041$ \\
\hline
\end{tabular}

Table 5

Correlations between the indices of smoking intensity and the degree of arterial hypertension

\begin{tabular}{lc}
\hline \multicolumn{1}{c}{ Parameters } & Arterial hypertension degree \\
\hline Duration of smoking (years) & $r=0.148 ; p=0.330$ \\
\hline Pack-year index & $\begin{array}{r}r=0.298 ; p=0.047 \\
\text { Gamma }=0.299 ; p=0.033 \\
\text { Age at starting smoking (years) }\end{array} \begin{array}{r}R_{S}=-0.341 ; p=0.022 \\
\text { Gamma }=-0.401 ; p=0.005\end{array}$ \\
\hline
\end{tabular}

tendencies were determined analyzing the carbohydrate metabolism. Thus, in smoking patients of groups 2 and 3 without concomitant DM there was revealed statistically significant negative correlation of the age at starting smoking with $\mathrm{HbA1c}\left(\mathrm{R}_{\mathrm{S}}=-0.381 ; \mathrm{p}=0.049\right)$.

The degree of arterial hypertension was estimated to grow with the increase of pack-year index (Table 5). A negative correlation was found between the age at starting smoking and the arterial pressure level.

Thus, obesity, metabolic syndrome, DM and hypertension disease are commonly accompany BA in smoking patients, which results in aggravation of the general disease severity and requires the revision of the treatment program. Long-term and intensively smoking patients with asthma are characterized by addition of COPD and the development of overlap syndrome having an extremely severe course. Along with bronchopulmonary events, frequent comorbid diseases such as abdominal visceral obesity, DM and hypertension disease aggravate the general disease severity in these patients. It is impossible to reveal fine mechanisms of forming combined pathology without application of a wide range of currently available statistical methods.

Conclusion. Some state-of-the-art examination methods, easily available in the clinical practice, play an important role in the diagnosis of the comorbid endocrine pathology in bronchial asthma. To diagnose visceral obesity, it is reasonable to perform waist measurements and bioelectrical impedance analysis. The assessment of carbohydrate metabolism and its regulation as well as diagnosing hyperinsulinemia and diabetes mellitus requires not only blood glycemic indices, but investigations of glycated hemoglobin, immunoreactive insulin and C-peptide will be also useful in this case.

Study Funding. The work was not supported by any financial sources.

Conflicts of Interest. The authors declare no conflicts of interest.

\section{References}

1. Astaf'eva N.G., Gamova I.V., Udovichenko E.N., Perfilova I.A. Obesity and bronchial asthma (part 1). Lechashchiy vrach 2014; 4: 8.

2. Global'naya strategiya diagnostiki, lecheniya i profilaktiki khronicheskoy obstruktivnoy bolezni legkikh (peresmotr 2011 g.) [Global strategy of diagnosis, treatment and prevention of chronic obstructive pulmonary disease (updated 2011)]. Pod red. Belevskogo A.S. [Belevskiy A.S. (editor)]. Moscow: Rossiyskoe respiratornoe obshchestvo; 2012.

3. Budnevskiy A.V., Chernov A.V., Ermolova A.V., Tribuntseva L.V. Co-morbidity of bronchial asthma and metabolic syndrome: possibilities to achieve asthma control. Russian Pulmonology 2014; 5: 39-45.

4. Astaf'eva N.G., Gamova I.V., Udovichenko E.N., Perfilova I.A. Obesity and bronchial asthma (part 2) Lechashchiy vrach 2014; 5: 100.

5. Mineev V.N., Lalaeva T.M., Vasilyeva T.S., Trofimov V.I. Phenotype of bronchial asthma with obesity. Russian Pulmonology 2012; 2: 102-107.

6. Sysoeva M.S., Solovieva A.V., Nikiforov A.A., Rakita D.R. Influence of metabolic syndrome on the course of bronchial asthma. Rossiyskiy mediko-biologicheskiy vestnik im. akademika I.P. Pavlova 2011; 4: 93-98.

7. Uryas'ev O.M., Panfilov Yu.A. Bronchial asthma and metabolic syndrome: some aspects of comorbidity. Mezhdunarodnyy endokrinologicheskiy zhurnal 2008; 3(15): 15-25.

8. Ermolova A.V., Budnevskiy A.V., Drobysheva E.S Bronchial asthma and metabolic syndrome: clinicalpathological relations. Molodoy uchenyy 2014; 6: 291-294.

9. Beyther D.A., Sutherland E.R. Over weight, obesity and incident asthma: a meta-analysis of prospective epidemiologic studies. Am J Resp Crit Care Med 2007; 175: 661-667, https:// doi.org/10.1164/rccm.200611-17170C.

10. Yeh K.H., Skowronski M.E., Coreno A.J., Seitz R.E., Villalba K.D., Dickey-White H., McFadden E.R. Impact of obesity on the severity and therapeutic responsiveness of acute episodes of asthma. J Asthma 2011; 8(6): 546-552, https://doi.org/10.3109/02770903.2011.581733.

11. Tsibulkina V.N., Tsibulkin N.A. Asthma and obesity: coincidence or pattern? Prakticheskaya meditsina 2011; 6(54): 36-41.

12. Shore S.A. Obesity and asthma: possible mechanisms J Allergy Clin Immunol 2008; 121(5): 1087-1093, https://doi. org/10.1016/j.jaci.2008.03.004.

13. Saint-Pierre P., Bourdin A., Chanez P., Daures J.-P., Godard P. Are overweight asthmatics more difficult to control? Allergy 2006; 61(1): 79-84, https://doi.org/10.1111/j.13989995.2005.00953.x.

14. Global'naya strategiya lecheniya $i$ profilaktiki 
bronkhial'noy astmy (peresmotr 2014 g.) [Global strategy for asthma management and prevention (updated 2014)]. Pod red. Belevskogo A.S. [Belevskiy A.S. (editor)]. Moscow: Rossiyskoe respiratornoe obshchestvo; 2015.

15. Belevskiy A.S. Syndrome of bronchial asthma and chronic obstructive pulmonary disease overlap (based on the joint document of the GINA and GOLD working groups of experts). Prakticheskaya pul'monologiya 2014; 2: 12-19.

16. Trofimov V., Mironova Zh., Belash V. Overlap syndrome of chronic obstructive pulmonary disease-asthma. Vrach 2013; 2: 20-21.
17. Proekt rekomendatsiy ekspertov Rossiyskogo kardiologicheskogo obshchestva po diagnostike i lecheniyu metabolicheskogo sindroma (3-y peresmotr) [Draft recommendations of experts from the Russian Society of Cardiology for the diagnostics and treatment of metabolic syndrome (3rd updated)]. Moscow; 2013; 103 p.

18. Likhonosova A.P., Likhonosov N.P., Kuznetsova O.G. Analysis of methods for determining the level of glycosylated hemoglobin as used in health care facilities in Saint Petersburg. Mezhdunarodnyy endokrinologicheskiy zhurnal 2010; 6(30): 23-27. 